\title{
Diversity of endophytic fungi from Vernonia amygdalina, their phenolic and flavonoid contents and bioactivities
}

\author{
PRAPTIWI ${ }^{1, \bullet}$, AHMAD FATHONI ${ }^{1}$, M. ILYAS ${ }^{2}$ \\ ${ }^{1}$ Botany Division, Research Center for Biology, Indonesian Institute of Sciences. Jl. Raya Jakarta-Bogor Km. 46, Cibinong, Bogor 16911, West Java, \\ Indonesia. Tel.: +62-21-8765066, `email: praptiwip@yahoo.com \\ ${ }^{2}$ Microbiology Division, Research Center for Biology, Indonesian Institute of Sciences. Jl. Raya Jakarta-Bogor Km. 46, Cibinong, Bogor 16911, West \\ Java, Indonesia
}

Manuscript received: 8 November 2019. Revision accepted: 3 January 2020.

\begin{abstract}
Praptiwi, Fathoni A, Ilyas M. 2020. Diversity of endophytic fungi from Vernonia amygdalina, their phenolic and flavonoid contents and bioactivities. Biodiversitas 21: 436-441. There are nine endophytic fungi in total associated with stem and leaves of Vernonia amygdalina were determined for their total phenolic and flavonoids content as well as assessed for their antibacterial and antioxidant activities. Total phenolic and flavonoid contents were determined by spectrophotometric methods. The antibacterial activity was performed using Thin Layer Chromatography (TLC) - Bioautography assay against S.aureus and E.coli. The antioxidant activity was carried out using TLC- Bioautography by DPPH scavenging assay. Broth serial microdilution assay was used to determine the minimum inhibitory concentrations (MIC) and the half-maximum inhibitory concentration (IC50). Among the identified isolates, there was one isolate of Phomopsis sp., two isolates of Phoma sp., two isolates of Lasiodiplodia sp., two isolates of Colletotrichum sp. and two isolates of Phyllosticta sp. The results showed that the phenolic contents were ranging from $0.53-116.03 \mathrm{mg}$ GAE/g extract, flavonoids contents were ranging from 81.12 to $390.21 \mathrm{mg}$ quercetin equivalent (QE)/g extract. MICs of endophytic fungi against S.aureus and E.coli ranged from 256 to $>256 \mu \mathrm{g} / \mathrm{mL}$ and $>256 \mu \mathrm{g} / \mathrm{mL}$ respectively that categorized as moderate antibacterial activity. The antioxidant activity of endophytic fungi associated with $V$. amygdalina was $>128 \mu \mathrm{g} / \mathrm{mL}$, and the antioxidant activity index (AAI) was 0.24 .
\end{abstract}

Keywords: Bioactivities, endophytic fungi, flavonoids, total phenolic, Vernonia amygdalina

\section{INTRODUCTION}

Endophytic fungi widely exist in the healthy plant tissues (Jia et al. 2016) without causing apparent symptoms of disease or harm to the host plant (Gouda et al. 2016). Each species of plant is the host to one or more endophytic fungal species (Strobel and Daisy 2003). Biological diversity of endophytic fungi is very high, and it is estimated over one million species of endophytic fungi in nature (Faeth and Fagan 2002). Endophytes produce phytohormones, and other bioactive compounds that can enhance the growth of host plants, improve the ability of plants to tolerate various abiotic and biotic stresses and enhance plant resistance to insects and pests (Joseph and Priya 2011).

Endophytes are a promising source of novel natural bioactive compounds (Pupo et al. 2006; Qian et al. 2014) with potential applications in medicine, agriculture, and food industry (Zhao et al. 2010). Many valuable bioactive compounds have been discovered from endophytic fungi with pharmacological properties, including antimicrobial, cytotoxic /anticancer, antimalarial, and antioxidant activities (Zhao et al. 2010). Besides, Zhao et al. (2010) stated that some endophytic fungi could produce the same or similar bioactive compounds to those originated from the host plants. Based on the ability of endophytes to produce bioactive compounds that are the same or similar to their host plants, research on endophytes associated with medicinal plants is very important to carry out.

Vernonia amygdalina is a plant species belonging to the family of Compositae, and commonly called as bitter-tea vernonia (Hyde et al. 2019). Vernonia amygdalina has been used in traditional medicine to cure diseases. Several studies on the bioactivity of $V$. amygdalina extract and its endophytes have been carried out. Plant extract of $V$. amygdalina has been used in traditional medicine against bacterial, helminthic, and protozoal infections and its bioflavonoids can scavenge free radicals (Farombi and Owoeye 2011). The previous study by Habtamu and Melaku (2018) showed that vernolide isolated from the flower of $V$. amygdalina possesses antibacterial activity whereas, isorhamnetin possess antibacterial and antioxidant activity. A study by Okezie et al. (2017) on endophytic fungi associated with $V$. amygdalina showed that they could be a promising source of novel antimicrobial compounds.

However, several factors also affect the association of endophytic fungal population in the host plant. The ecological and environmental conditions, such as temperature, humidity, and soil 
nutrient level are important factors that determine the types and amount of secondary metabolites of the host plant, that will indirectly affect the structure of endophytic fungal populations. Understanding the distribution and structure pattern of endophytic fungal populations will provide theoretical guidance to effectively explore the bioactive compounds produced by special hosts medicinal plants in particular tissues under special environmental conditions (Jia et al. 2016). Considering that environment and other factors may influence the population structure of endophytic fungi and their bioactive compounds, the purpose of this study was to determine the diversity of endophytic fungi associated with $V$. amygdalina that grows in the Cibinong Science Center, Bogor, West Java, Indonesia and to determine phenolic content, flavonoids content and their bioactivity as antibacterial and antioxidant.

\section{MATERIALS AND METHODS}

\section{Plant collection and isolation of endophytic fungi}

Healthy leaves and stems of $V$. amygdalina were collected from Cibinong Science Center, Bogor, West Java, Indonesia. The plant samples were washed under tap water and surface sterilized with $70 \%$ ethanol for 1 min, followed by 5\% Sodium hypochlorite for $3 \mathrm{~min}$, and then $70 \%$ alcohol for $0.5 \mathrm{~min}$, subsequently rinsed with sterile distilled water and drained. The sterilized samples were cut into small pieces and placed on the Corn Meal Malt Agar (CMMA) supplemented with $0.05 \mathrm{~g} / \mathrm{L}$ chloramphenicol for suppressing bacterial growth, and then incubated at room temperature for one week. The emergence of hyphal tips was sub-cultured on potato dextrose agar (PDA) several times to get pure isolate.

\section{Identification of endophytic fungi}

The identification of endophytic fungi was carried out based on morphological characters of endophytic fungi by observing both macroscopic and microscopic phenotypic characteristics. Macroscopic characterization includes observation on color, colony shape, surface, texture, exudates drop, and reverse color. Microscopic observation was prepared by the tease mount method using one drop of $1 \%$ lactophenol blue staining and then observed under a light microscope. Microscopic characters include hyphae pigmentation, septate, clamp connection, spore, and other reproductive structures.

Extraction of secondary metabolites from endophytic fungi

A loopful of endophytic fungi was inoculated in $200 \mathrm{ml}$ of Potato Dextrose Broth (PDB) media in $500 \mathrm{ml}$ conical flask under the static condition at room temperature, the dark condition for three weeks. After incubation, biomass of fungi and growth media was macerated with ethyl acetate for 24 hours. The ethyl acetate fraction was separated by using separating funnel and concentrated with rotary evaporator under reduced pressure. It was done thrice. The concentrated ethyl acetate extract was stored at low temperature for further use. Ethyl acetate extraction is the most efficient method of isolating secondary metabolites from fungal species (Yadav et al. 2014)

\section{Antibacterial activity assay}

Screening of antibacterial activity was performed by Thin-Layer Chromatography (TLC)- Bioautography by Dot-Blot method and Eluted TLC against Staphylococcus aureus Ina-CC B1 and Escherichia coli Ina-CC B2 collected from Indonesia Culture Collection of Microbiology Division, Research Center for Biology. Ten microliters of extract at the concentration of $10 \mathrm{mg} / \mathrm{mL}$ were loaded onto the TLC silica plate (Merck F254). After finish loading the extract, plates were dried and dipped in a suspension of test bacteria at the density of $10^{8} \mathrm{CFU} / \mathrm{mL}$. On the other plates, ten microliters of extract were loaded onto a TLC silica plate (Merck F254) and dried. Plates were then eluted using a mobile solvent system of dichloromethane: methanol (10: 1). All the works were carried out aseptically in the laminar flow cabinet. The eluted plates were dipped in a suspension of test bacteria. Plates from Dot-Blot method and eluted plates that have been dipped in bacterial suspension were incubated under the humid condition for 18 hours at $37^{\circ} \mathrm{C}$. After that, plates were sprayed with a solution of $2 \mathrm{mg} / \mathrm{mL}$ piodonitrotetrazolium (Sigma, INT). White spot or white bands indicate the growth inhibition of test bacteria.

\section{Determination of Minimum Inhibitory Concentration (MIC)}

Two-fold broth microdilution in a 96-well microplate was carried out to determine the Minimum Inhibitory Concentration (MIC) value of endophytic extracts. Wells in the first row were loaded with $100 \mu \mathrm{L}$ of double strength of Mueller Hinton Broth, $10 \mu \mathrm{L}$ of extract $(10.24 \mathrm{mg} / \mathrm{mL}$ Dimethyl sulfoxide (DMSO)), and 90 sterile aqua dest and homogenized. Wells of the $2^{\text {nd }}$ to $4^{\text {th }}$ row was filled with $100 \mu \mathrm{L}$ Mueller Hinton Broth. One hundred $\mu \mathrm{L}$ of the $1^{\text {st }}$ well was taken out and transferred into the $2^{\text {nd }}$ well of a vertical row and homogenized. Serial dilution was carried out until the $4^{\text {th }}$ row, and at the $4^{\text {th }}$ row, $100 \mu \mathrm{L}$ of the mixture was discarded. After that, $100 \mu \mathrm{L}$ of bacterial suspension $\left(10^{6} \mathrm{CFU} / \mathrm{mL}\right)$ was added into each well, followed by incubation of the microwell plate for 18 hours at $37^{\circ} \mathrm{C}$. After incubation, each well was added with $10 \mu \mathrm{L}$ INT. The lowest concentration before the color changes is MIC value (The et al. 2017)

\section{Antioxidant activity assay}

Screening for antioxidant activity of endophytic fungi was carried out by TLC-Bioautography with DPPH reagent (Dot-Blot and Eluted Plates). At the Dot-Blot technique, ten microliters of extract at the concentration of $10 \mathrm{mg} / \mathrm{mL}$ were loaded onto TLC silica plate (Merck F254), dried, and sprayed with $0.2 \%$ DPPH solution in methanol. Antioxidant activity was observed at 30 minutes after DPPH spraying. The yellowish spot on the purple background indicates antioxidant activity. At the eluted plates, ten microliters of extract at the concentration of 10 
$\mathrm{mg} / \mathrm{mL}$ were loaded onto TLC silica plate (Merck F254), dried, and developed with an eluent system of dichloromethane: methanol (10: 1). Plates were sprayed with $2 \%$ DPPH solution in methanol, and the antioxidant activity was examined at 30 minutes after spraying. White bands indicated antioxidant compounds. Gallic acid was used as a positive control.

\section{Determination of $I_{50}$ for antioxidant activity}

The $\mathrm{IC}_{50}$ value for antioxidant activity was carried out by serial microdilution in a 96-well microplate. Wells in the first row was filled with $195 \mu \mathrm{L}$ methanol and $5 \mu \mathrm{L}$ endophytic extract $(10.24 \mathrm{mg} / \mathrm{mL})$ and homogenized. Wells in the next row until $4^{\text {th }}$ row at the vertical row was filled with $100 \mu \mathrm{L}$ methanol. One hundred $\mu \mathrm{L}$ was taken out from the $1^{\text {st }}$ row and transferred to well in the second at the same vertical row and homogenized. It carried out until the $4^{\text {th }}$ row. One hundred $\mu \mathrm{L}$ was taken out from the $1^{\text {st }}$ row and discarded. And then, each well was filled with $100 \mu \mathrm{L}$ DPPH solution in methanol $(61.5 \mathrm{mg} / \mathrm{mL})$ followed by incubation for 90 minutes under the dark condition at room temperature. The absorbance of DPPH used as control. After 90 minutes of incubation, the absorbance was measured at the wavelength of $517 \mathrm{~nm}$ with a microplate reader (Varioskan Flash). The antioxidant activity was calculated as follows:

$$
\text { Antioxidant activity }=\frac{\text { Ao-A }}{\text { Ao }}
$$

Where, $\mathrm{A}_{\mathrm{o}}$ : absorbance of the control, $\mathrm{A}$ : absorbance of extract at various concentrations

The $\mathrm{IC}_{50}$ values of the endophytic extract were calculated using regression analysis, while the antioxidant activity index (AAI) was calculated by the following formula:

$$
\mathrm{AAI}=\text { Final concentration of } \mathrm{DPPH} / \mathrm{IC}_{50}
$$

\section{Estimation of total phenolic content}

Estimation of total phenolic content $\mathrm{f}$ endophytic extract was determined by the Folin-Ciocalteau spectrophotometric assay (Ismail et al. 2012). Briefly, 200 $\mu \mathrm{L}$ of ethanolic solution of endophytic extract $(1 \mathrm{mg} / \mathrm{mL})$ added with $200 \mu \mathrm{L}$ of $50 \%$ Folin Ciocalteau reagent, vortex for $1 \mathrm{~min}$. After that, $4 \mathrm{ml}$ of $2 \%$ sodium carbonate was added to the mixture and incubated at room temperature under the dark condition for $30 \mathrm{~min}$. The absorbance was determined at $750 \mathrm{~nm}$ using a UV-Vis spectrophotometer. It was carried out in triplicate. The procedure was also carried out for gallic acid as a standard solution with concentration ranged from $6.25-200 \mu \mathrm{g} / \mathrm{mL}$ for constructed the calibration line. Total phenolic content was expressed as gallic acid equivalent ( $\mathrm{mg}$ of $\mathrm{GA} / \mathrm{g}$ extract).

\section{Estimation of total flavonoid content}

Total flavonoid content was determined by spectrophotometric using aluminum chloride according to the method by Zou et al. (2004). $500 \mu \mathrm{L}$ of ethanolic solution of endophytic extract $(1 \mathrm{mg} / \mathrm{mL})$ added with $2 \mathrm{ml}$ distilled water, $0.15 \mathrm{ml}$ of $5 \% \mathrm{NaNO}_{2}$, then incubated for 6 minutes. After incubation, the mixture was added with 0.15 $\mathrm{ml}$ of $10 \% \mathrm{AlCl}_{3}$, vortex, and incubated again for 6 minutes, then added with $2 \mathrm{ml}$ of $1 \mathrm{~N} \mathrm{NaOH}$ and distilled water to the total volume of $5 \mathrm{ml}$ and incubated for 15 minutes at room temperature. The absorbance was determined at $510 \mathrm{~nm}$ using a UV-Vis spectrophotometer. It was carried out in triplicate. The procedure was also carried out for quercetin as a standard solution with concentration ranged from 31.25-1000 $\mu \mathrm{g} / \mathrm{mL}$ for constructed the calibration line. Total phenolic content was expressed as quercetin equivalent (mg of QE/g extract).

\section{RESULTS AND DISCUSSION}

\section{Identification of endophytic fungi associated with Vernonia amygdalina}

A total of nine endophytic fungal isolates successfully isolated from the stem and leaf of V.amygdalina grows in the Cibinong Science Center, Cibinong-Indonesia. Based on the macroscopic and microscopic identification, the fungal isolates were identified as belonging to 5 genera, i.e., Phomopsis sp., Phoma sp., Lasiodiplodia sp., Colletotrichum sp., and Phyllosticta sp. (Table 1.).

\section{Determination of antibacterial activity}

Antibacterial activity of endophytic fungal extract associated with $V$. amygdalina was performed by Bioautography technique because of it cheap, fast, and allows the localization of antimicrobial activity directly on chromatographic plate (Navarro et al. 1998)

Table 1. Endophytic fungi associated with Vernonia amygdalina

\begin{tabular}{lcl}
\hline Isolate code & Part of the plant & Taxa of fungi \\
\hline BDA-1 & Stem & Phomopsis sp. \\
BDA-2 & Stem & Phoma sp. \\
BDA-3 & Stem & Lasiodiplodia sp \\
BDA-4 & Stem & Colletotrichum sp. \\
BDA-5 & Stem & Lasiodiplodia sp. \\
BDA-6 & Stem & Phoma sp. \\
DDA-1 & Leaf & Colletotrichum sp. \\
DDA-1 & Leaf & Phyllosticta $\mathrm{sp}$. \\
DDA-1 & Leaf & Phyllosticta $\mathrm{sp}$. \\
\hline
\end{tabular}

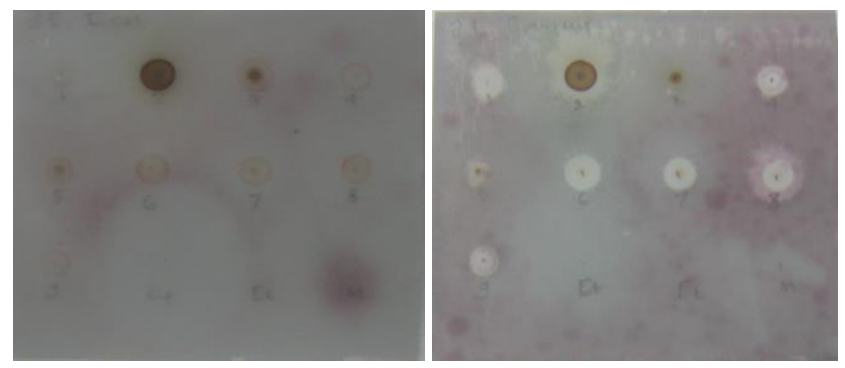

Figure 1. Bioautograms of endophytic fungi associated with Vernonia amygdalina for antibacterial activity by TLC-Dot Blot against E. coli (left) and S.aureus (right) 
Bioautogram of antibacterial of endophytic fungi showed the appearance of the white zone around the test extract indicated the growth inhibition of test bacteria. All the endophytic extracts were determined further for their minimum inhibitory concentration (MIC) values against S.aureus and E.coli. The MIC of extracts against S.aureus ranged from $256->256 \mu \mathrm{g} / \mathrm{mL}$, while the MIC value of extracts against E.coli were $>256 \mu \mathrm{g} / \mathrm{mL}$ (Table 2). There were 4 extracts showed moderate antibacterial activity against S.aureus with the MIC value of $256 \mu \mathrm{g} / \mathrm{mL}$ (Pessini et al. 2003). However, all extracts showed weak antibacterial activity against E.coli (MIC>256 $\mu \mathrm{g} / \mathrm{mL}$ )

\section{Detection of antioxidant activity}

Detection of antioxidant activity of the endophytic fungi extract was carried out by TLC-Dot Blot DPPH staining method on TLC plate and the elution of extract with a mobile phase of dichloromethane: methanol (10: 1) (Fig. 2).

Chromatogram of Dot-Blot assay showed that several extracts possess antioxidant activity indicated by a yellowish spot against the purple background. The result of Dot-Blot technique similar to the result in the eluted extract, in which extract no. $3 ; 5$; and 8 have the white spot as indication of antioxidant activity that was measured by DPPH free radical scavenging activity. Determination of the $\mathrm{IC}_{50}$ value and antioxidant activity index of extracts showed that all extracts of endophytic fungi associated with V.amygdalina have weak antioxidant activity $\left(\mathrm{IC}_{5}>128\right.$ $\mu \mathrm{g} / \mathrm{mL}$, with AAI 0.024) (Table 2).

\section{Total phenolic and flavonoid content}

Total phenolic and flavonoid contents of endophytic fungi were performed by the colorimetric method. The total phenolic content of extracts was quantified by the regression linear of gallic acid as standard with the equation: $y=0.0048 x+0.093, R^{2}=0.9995$. Based on the $R^{2}$ value, it was indicated that the linear relationship was good for the detection of total phenolic content. The result in Table 2. showed high variations of total phenolic of endophytic fungal extract, ranged from 0.534-116.034 mg $\mathrm{GA} / \mathrm{g}$ extract.

The total flavonoid content of endophytic fungal extract also quantified by the regression linear of quercetin as standard with the equation: $\mathrm{y}=0.0073 \mathrm{x}-0.0061$, $\mathrm{R}^{2}=0.9996$. The highest content of flavonoid was found in the extract of DDA-3 (Phyllosticta sp., $405 \mathrm{mg}$ QE/g extract), and the lowest was in the extract of BDA-4 (Colletotrichum sp., $81.121 \mathrm{mg}$ QE/g extract). BDA-4 also has the lowest total phenolic content.

\section{Discussion}

The isolation of endophytic fungi showed several endophytes colonize V.amygdalina in diverse taxa. The distribution pattern and population structure of endophytic fungi were significantly associated with variation in environments (Jia et al. 2016). According to Jiang et al. (2010), species and population structure of endophytic fungi in the same host plant from different regions have a very low degree of similarity. Because of variation in the environment, it is important to investigate potential bioactivity of endophytic fungi from the same species of the host plant in different regions.
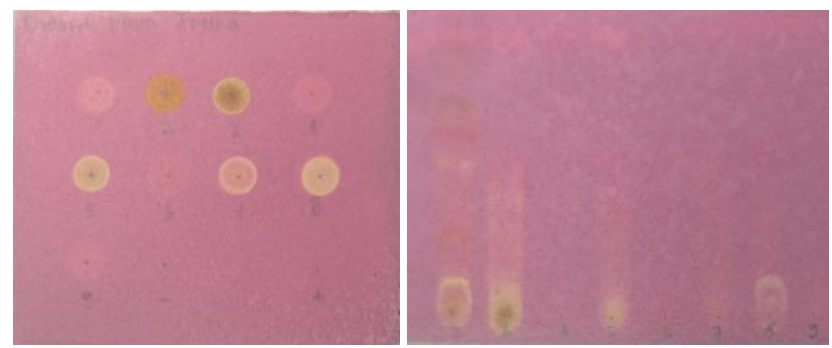

Figure 2. Chromatograms of endophytic fungal extract for detection of antioxidant activity, sprayed with $0.2 \%$ DPPH in methanol, by Dot-Blot technique (left) and developed with eluent system of dichloromethane: methanol (10: 1) (right)

Table 2. Total flavonoid content, total phenolic content, MIC, and $\mathrm{IC}_{50}$ of endophytic fungi extract associated with Vernonia amygdalina

\begin{tabular}{|c|c|c|c|c|c|c|c|}
\hline \multirow{2}{*}{ Isolate Code } & \multirow{2}{*}{ Taxa of Fungi } & \multirow{2}{*}{$\begin{array}{l}\text { Total phenolic (mg } \\
\text { GA/g extract) }\end{array}$} & \multirow{2}{*}{$\begin{array}{l}\text { Total flavonoid (mg } \\
\text { QE/g extract) }\end{array}$} & \multicolumn{2}{|c|}{ MIC $(\mu \mathrm{g} / \mathrm{mL})$} & \multirow{2}{*}{$\begin{array}{c}\mathrm{IC}_{50} \\
(\mu \mathrm{g} / \mathrm{mL})\end{array}$} & \multirow{2}{*}{ AAI } \\
\hline & & & & S.aureus & E.coli & & \\
\hline BDA-1 & Phomopsis sp. & 13.881 & 103.303 & 256 & $>256$ & $>128$ & 0.240 \\
\hline BDA-2 & Phoma sp. & 116.034 & 390.212 & $>256$ & $>256$ & $>128$ & 0.240 \\
\hline BDA-3 & Lasiodiplodia sp & 86.437 & 159.030 & $>256$ & $>256$ & $>128$ & 0.240 \\
\hline BDA-4 & Colletotrichum sp. & 0.534 & 81.121 & 256 & $>256$ & $>128$ & 0.240 \\
\hline BDA-5 & Lasiodiplodia sp & 22.930 & 121.333 & $>256$ & $>256$ & $>128$ & 0.240 \\
\hline BDA-6 & Phoma sp. & 9.118 & 183.454 & $>256$ & $>256$ & $>128$ & 0.240 \\
\hline DDA-1 & Colletotrichum sp. & 26.152 & 299.606 & 256 & $>256$ & $>128$ & 0.240 \\
\hline DDA-2 & Phyllosticta sp. & 15.819 & 181.666 & 256 & $>256$ & $>128$ & 0.240 \\
\hline DDA-3 & Phyllosticta sp. & 7.118 & 405 & $>256$ & $>256$ & $>128$ & 0.240 \\
\hline
\end{tabular}


Phenolic compounds, as well as flavonoids, are important bioactive agents due to their benefits for human health, curing and preventing many diseases (Tungmunnithum et al. 2018) Phenolic compounds commonly known to possess antioxidant properties (Andreu et al. 2018). In addition, many phenolic compounds and flavonoids have been reported to have antibacterial activity (Lim et al. 2007; Tsai et al. 2016). Total phenolic and flavonoids content of endophytes associated with V.amygdalina were significantly varied.

Previous studies revealed that endophytic fungi associated with medicinal plants produce potential bioactive compounds. In this study, the endophytic fungi associated with $V$. amygdalina were investigated for total phenolic, total flavonoid, antibacterial, and antioxidant activity. The TLC- bioautography technique was applied to determine the antibacterial and antioxidant activity of the endophytic fungal extract. In the antibacterial assay, the active antibacterial activity was assessed by the appearance of white spots. The white area is formed due to the presence of antibacterial compounds that inhibit the growth of test bacteria, so there was no occurrence of iodo nitro tetrazolium (INT) reduction to colored formazan (Suleimana et al. 2010; Masoko 2017). INT interacted with viable microorganisms caused a color change to purple (Shaverdi et al. 2007) by the hydrogenase enzymes (Silva et al. 2005). The result of bioautography for antibacterial activity also showed that $S$. aureus (Gram-positive bacteria) is more sensitive to endophytic fungi extracts than E.coli (Gram-negative bacteria). Eight extracts were able to inhibit the growth of $S$. aureus, as indicated by the formation of white areas. Several studies have shown differences in susceptibility to antimicrobials between Gram-positive and Gram-negative bacteria related to the structure and composition of cell walls (Shrivastava et al. 2007; Tamboli and Lee 2003). The cell wall of Gramnegative bacteria is more complex, constituted by a thin peptidoglycan layer adjacent to the cytoplasmic membrane and an outer membrane (OM) composed by phospholipids and lipopolysaccharides (LPS) (Nazzaro et al. 2013). Antibacterial activity of endophytes categorized as moderate to weak. The result of this study is in agreement with Okezie et al. (2017) that endophytic fungi from V.amygdalina have mild antibacterial activity against several bacteria isolates.

In this study, the antioxidant activity of fungal endophytes was also evaluated by TLC-Bioautography sing DPPH as an indicator reagent. DPPH free radical scavenging assay is considered to be the most accurate screening method used to evaluate the antioxidant activity (Gunasekaran et al. 2017). The antioxidant assay with DPPH as indicator reagent was based on the inhibition of free radicals generated by the presence of antioxidant compounds (Arora and Chandra 2010). DPPH reacts with a reducing agent that capable of donating electron/hydrogen atoms to convert purple DPPH into a colorless non-radical form of 1, 1-diphenyl-2- picrylhydrazine (Kedare and Singh 2011; Nithya and Khan 2014). The intensity of yellowish color could be used as an indication of antioxidant capacity (Praptiwi et al. 2018).
The results of antibacterial and antioxidant activity of this study were not affected by either total phenolic content or flavonoids content. Nickawar et al. (2007) and Wojdylo et al. (2007) stated that structure of flavonoid and hydroxyl position in the molecule affecting the ability of flavonoid to act as proton donating and radical scavenging activity. Kaur and Mondal (2014) also stated that different types of phenolic compounds have different antioxidant activities that depend on their structure. In conclusion, this study showed that endophytic fungi associated with V.amygdalina could be promising sources for antimicrobial compounds.

\section{ACKNOWLEDGEMENTS}

The authors thank Ersaliani Dewi Pratiwi Qodri for assistance in laboratory analysis.

\section{REFERENCES}

Andreu L, Nuncio-Jáuregui, N, Carbonell-Barrachina ÁA, Legua P, Hernández F. 2018. Antioxidant properties and chemical characterization of Spanish Opuntia ficus-indica Mill. cladodes and fruits. J. Sci. Food Agric. 98: 1566-1573.

Arora DS, Chandra P. 2010. Assay of antioxidant potential of two potential Aspergillus isolates by different methods under various physicochemical conditions. Braz J Microbiol 41(3): 765-777. DOI: $10.1590 \%$ 2FS1517-83822010000300029

Faeth SH,and Fagan WF. 2002. Fungal endophytes: common host plant symbionts but uncommon mutualists. Integr Comp Biol 42: 360-368. DOI: $10.1093 / \mathrm{icb} / 42.2 .360$

Farombi EO, Owoeye O. 2011. Antioxidative and chemopreventive properties of Vernonia amygdalina and Garcinia biflavonoid. Intl J Environ Res Public Health 8: 2533-2555. DOI: 10.3390/ijerph8062533.

Gouda S, Das G, Sen SK, Shin H-S, Patra JK. 2016. Endophytes: A treasure house of bioactive compounds of medicinal importance. Front Microbiol 7: 1538. DOI: 10.3389/fmicb.2016.01538.

Gunasekaran S, Sathiavelu M, Arunachalam S. 2017. In vitro antioxidant and antibacterial activity of endophytic fungi isolated from Mussaenda luteola. J App Pharm Sci 7 (8): 234-238.

Habtamu A, Melaku Y. 2018. Antibacterial and antioxidant compounds from the flower extracts of Vernonia amygdalina. Adv Pharmacol Sci 2018: ID 4083736. DOI: 10.1155/2018/4083736

Hyde MA, Wursten BT, Ballings P, Coates Palgrave M. 2019. Flora of Zimbabwe: Species information: Vernonia amygdalina. https: //www.zimbabweflora.co.zw/speciesdata/species.php?species_id=158 120, [2 December 2019].

Ismail J, Runtuwene MRJ, Fatimah F. 2012. Penentuan total fenolik dan uji aktivitas antioksidan pada biji dan kulit buah pinang Yaki (Areca vestiaria Giseke). Jurnal Ilmiah Sains 12 (2) : 84-88. [Indonesian]

Jia M, Chen L, Xin H-L, Zheng C-J, Rahman K, Han T, Qin L-P .2016. A friendly relationship between endophytic fungi and medicinal plants: A Systematic Review. Front Microbiol 7: 906. DOI: 10.3389/fmicb.2016.00906

Jiang S, Duan JA, Tao JH, Yan H, Zheng JB.2010. Ecological distribution and elicitor activities of endophytic fungi in Changium smyrnioides. Chin Tradit Herb Drugs 1: 121-125.

Joseph B, Priya RM. 2011. Bioactive compounds from endophytes and their potential in pharmaceutical effect: a review. Am J Biochem Mol Biol 1: 291-309. DOI: 10.3923/ajbmb.2011.291.309

Kaur S, Mondal P. 2014. Study of total phenolic and flavonoid content antioxidant activity and antimicrobial properties of medicinal plants. $\mathbf{J}$ Microbiol Exp 1 (1): 23-28.

Kedare SB, Singh RP. 2011. Genesis and development of DPPH method of antioxidant assay. J Food Sci Technol 48: 412-22

Lim Y-H, Kim I-H, Seo J-J.2007. In vitro activity of kaempferol isolated from the Impatiens balsamina alone and in combination with 
erythromycin or clindamycin against Propionibacterium acnes. J Microbiol 45: 473-477.

Masoko P. 2017. Phytochemical analysis, antioxidant and antibacterial properties of Spilanthes mauritiana used traditionally in Limpopo Province, South Africa. J Evid-Based Compl Altern Med 22 (4): 936943.

Navarro, V, Rojas, G, Delgado, G, Lozoya, X. 1998. Antimicrobial compounds detected in Bocconia arborea extracts by direct bioautographic method. Arch Med Res 29: 191-194.

Nazzaro F, Fratianni F, De Martino L, Coppola R, De Feo V. 2013. Effect of essential oils on pathogenic bacteria. Pharmaceuticals 6 (12): 14511474. DOI: $10.3390 / \mathrm{ph} 6121451$.

Nickavar B, Kamalinejad M, Izadpanah H. 2007. In vitro free radical scavenging activity of five Salvia species. Pak J Pharm Sci. 20(4) 291-294.

Nithya P, Khan FRN. 2014. Antioxidant studies of 3-arylidene-4piperidones by DPPH assay. J Taibah Univ Sci 11 (1): 40-45. DOI: 10.1016/j.jtusci.2014.11.007

Okezie UM, Eze PM, Okoye FBC, Ikegbunam MN, Ugwu MC, Esimone CO. 2017. Biologically active metabolites of an endophytic fungus isolated from Vernonia amygdalina. Afr J Pharmaceut Res Dev 9 (1): 24-26.

Qian Y, Kang J, Kun Geng K, Wang L, Lei B. 2014. Endophytic fungi from Artemisia argyi Levl. et Vant. and their bioactivity. Chiang Mai J Sci 41 (4): 910- 921.

Praptiwi, Raunsai M, Wulansari D, Fathoni A, Agusta A. 2018 Antibacterial and antioxidant activities of endophytic fungi extract from medicinal plants from Central Sulawesi. J Appl Pharm Sci 8 (8): 69-74.

Pupo MT, Guimaraes DO, Furtado NAJC, Borges WS. 2006. Microbial natural products: a promising source of bioactive compounds. In: Taft CA (ed.). Modern Biotechnology in Medicinal Chemistry and Industry. Research Signpost, Kerala, India

Shahverdi AR, Abdolpour F, Monsef-Esfahani HR, Farsam H. 2007. A TLC bioautographic assay for the detection of nitrofurantoin resistance reversal compound. J Chromatogr B Analyt Technol Biomed Life Sci 850 (1-2): 528-530.
Shrivastava S, Bera T, Roy A, Singh G, Ramachandrarao P, Dash D. 2007. Characterization of enhanced antibacterial effects of novel silver nanoparticles. Nanotechnology 18 (22). DOI: 10.1088/09574484/18/22/225103.225103

Silva MTG, Simas SM, Batista TGFM. 2005. Studies on antimicrobial activity, in vitro, of Physalis angulata L. (Solanaceae) fraction and physalin B bringing out the importance of assay determination. Mem Inst Oswaldo Cruz 100: 779-782.

Strobel, G, Daisy B. 2003. Bioprospecting for microbial endophytes and their natural products. Microbiol Mol Biol Rev 67: 491-502.

Tamboli DP, Lee DS. 2013. Mechanistic antimicrobial approach of extracellularly synthesized silver nanoparticles against gram-positive and gram-negative bacteria. J Hazard Mater 260: 878-884. DOI: 10.1016/j.jhazmat.2013.06.003.

Tsai PJ, Huang WC, Hsieh MC, Sung PJ, Kuo YH, Wu WH. 2016. Flavones isolated from Scutellariae radix suppress Propionibacterium acnes-induced cytokine production in vitro and in vivo. Molecules 21 (1): E15. DOI: 10.3390/molecules21010015.

Tungmunnithum D, ThongboonyouA, Pholboon A, Yangsabai A. 2018. Flavonoids and other phenolic compounds from medicinal plants for pharmaceutical and medical aspects: an overview. Medicines 5: 93.

Wojdylo A, Oszmianski J, Czemerys R. 2007. Antioxidant activity and phenolic compounds in 32 selected herbs. Food Chem 105 (3): 940949.

Yadav M, Yadav A, Yadav JP. 2014. In vitro antioxidant activity and total phenolic content of endophytic fungi isolated from Eugenia jambolana Lam. Asian Pac J Trop Med 7 (1): S256-S261.

Zhao J, Zhou1 L, Wang J, Shan T, Zhong L, Liu X, Gao X. 2010. Endophytic fungi for producing bioactive compounds originally from their host plants. In: Mendez-Vilas A (ed.) Current Research, Technology and Education Topics in Applied Microbiology and Microbial Biotechnology, Formatex Research Center, Spain.

Zou Y, Lu Y, Wei D. 2004. Antioxidant activity of a flavanoids-rich extract of Hypericum perforatum L. in vitro. J Agric Food Chem 52 (16): 5032-5039. 